\title{
Silks, Velvets and Spices
}

Sophia Hall Glidden

Manuscript Division

THE papers of "Israel Thorndike, Esq." are the first manuscript collection arranged and mounted by Baker Library. They are fragmentary first hand tales of shipwrecks; of the capture and imprisonment of sailors and sea captains; of trading meat, metals and upland cotton for silks and spices (these were the early days of the American pepper trade), by bright, vivid young captains and supercargoes who were virtually agents of a wealthy house, and whose reports of the market and conditions in foreign seaport towns were a valuable portion of America's knowledge of foreign economic and political affairs. Very many of them are the sort that the files of a firm today would disclose, - deeds, bonds, contracts, bills, bank vouchers and memoranda of various sorts; and, in addition, others relating particularly to shipping, - charter parties of affreightment, bills of portage, bills of lading, impost and other bonds, insurance policies, et cetera. It is interesting to watch the evolution of modern business forms among them, - first, diverse, hand written papers; then printed, some with Puritanical, pious verbosity; and finally, uniform, almost modern printed forms - even bill heads and bank checks.

There are occasional more personal items, such as a bill in a feminine hand, "reconed and settled with Mrs Down 5 days works and a leg of porke, received the above Elizabeth $\times$ Down;" and mark

a recipe for "Russ cake” calling for “ $7^{\frac{1}{2}}$ flour, I qt yeast, 5 eggs, I oz alspice and a little salt. Then take 3 pints (new) milk * $2 \frac{1}{2}$ sugar and 6 oz butter, melt them together and when luke warm stirin the eggs - mix the whole together and when well rizen add $\# \mathrm{I} \frac{1}{2}$ currents." There are whole legal-sized sheets of bills for bread, and housewifely inventories of clothes, or books of the son who went to Bowdoin. A memorandum shows that his total expenses for term no. I were $\$ 62$, and $\$ 80$ for term no. 2. They charged about four shillings for making a silk dress in 1804 or 1805 , and gas (for the Tremont Row Bank) cost $3 \frac{1}{2}$ mills per foot in 1847 and I 848 . 
There is a small handfull of papers which contain a broken story. In the very early days of his firm Israel Thorndike sent out the ship "Sally." A letter tells much of the story: "Certify We left the port of Charlestown [meaning Charleston, S. C., as ascertained from other papers] on the 7 th day bound [for the West Indies]. . . O On the 8th we sprung a leak in Lat. $33 \mathrm{~W}$ Long. 77. I $7 \mathrm{~W}$ We were obliged to keep a pump constantly agoing on the ninth the wind shifted. We steered to the nearest [land] when we saw that we could nolonger hold it, not even with both pumps -, we thought proper to go about and steer with an aft wind in order to pump the water which we accomplished in three quarters of an hour. On the Ioth continuing to make a great deal of water, we took reefs. . . . We then [I th] shifted the sails so as to steer with an aft wind - The captain and mate threw the sounding lead and found four feet of water in the hold, - then we thought proper to steer our course for the West Indies and thus we came to Capfrancois - In consequence we do protest against the wind and weather. Mar.22,1790"

It appears from scattered memoranda that the "protest" was one of the early legal steps in a case brought to court. It seems that on its previous trip, the "Sally" had run aground on a sandbar near the dock at Charleston, South Carolina. There were five folded sheets of notes, questions in very legal phraseology, which had brief answers in a different hand. There was also a copy of a notorial report of the jury sent to examine the ship for the underwriters, which certified that there were: "I 5 timbers rotten-star board side 7 on the Larboard \& besides 4 split and incapable of holding nails. That in the hold they found five of the timbers on the starboard side \& four on the Larboard side which were entirely rotten - that to repair the vessel it is needing thirtyfive timbers which are rotten." Lastly, there was a paper folded to make a wrapper, marked: "Papers concerning the Ship Sally Dolliver Master, Higginson and Parsons owners, Brown and Thorndike \& others underwriters

Lawsute determined against underwriters etc. Papers are useless unless the underwriters sues the freighters for freight

$$
\text { July } 1797 "
$$

One of the letters - nearly the last of Thorndyke's own writing - gives quite the most complete picture of the kindness, force and foresight, and the fine consideration and tact of the man, to be 
found in any one document. It is addressed to William E. Touth, Esq. ". . I I have seen and conversed with the widow of the late Capt. Giles who I am sorry to say is left in rather indigent circumstances and of course it is very important to her and her family that the most possible should be made of what Capt. Giles left. - An impression seems to be made on the minds of the heirs that Capt. Giles had much more property than appears that he had from the statement you make, and they seem to fear that all the property which he left never came into your hands, and that some of it had been lost or plundered before it came to your hands amongst which is ment. his beding and cloathing, which they say was valuable, none of the former and very little of the latter has ever come to hand, not even to the value of $£_{5} \mathrm{stlg}$ in all. - I tell Mrs. Giles that so far as you have any agency in this unfortunate business she may depend on haveing justice done her, and that I would write to you and request of you to git all the information possible as to the detail of the accounts, inventory of the property, cloathing and so forth and what had become of them and therefore will thank you to furnish to Mrs. Giles every information, in detail, that you can. - From inquiry I fear that there is no insurance on the Brigt. that can be recovered, but I should suppose that Mrs. Giles can and will if necessary pay $£_{200}$ stlg if you should be unfortunate in the sute now pending in the appeal, I have assured this good unfortunate Lady that you will do all in our power to promote her interest, and I pray that you will make every exertion to produce a favourable issue in the cause now pending and that as soon as possible that this family may be relieved from the suspense under which they labr. - Mr. Robert Rogers who is a friend of mine and has some small acquaintance with Mrs. Giles family or rather a man in whom she would place great confidence is now on the point of sailing from New York for England, and it is her particular desire that you would prevail on Mr. Rogers to look into all the accounts of her late husband and give him every information about the property before and after his decease, that he might be able to give her the state of it and to see if he could trace any that has not fallen into your hands. - I shall write $\mathrm{Mr}$. Rogers this day, but he may be off from N. York before my letter reaches that city and therefore I have to request your finding $\mathrm{Mr}$. $\mathrm{R}$. and communicateing this Mrs. Giles and my request to him. I believe he has some business with Mr. Henry Higginson, I presume he may be found by inquiring of $\mathrm{Mr}$. H. -

I am with much respect

Your friend and obt. servn. Israel Thorndike" 


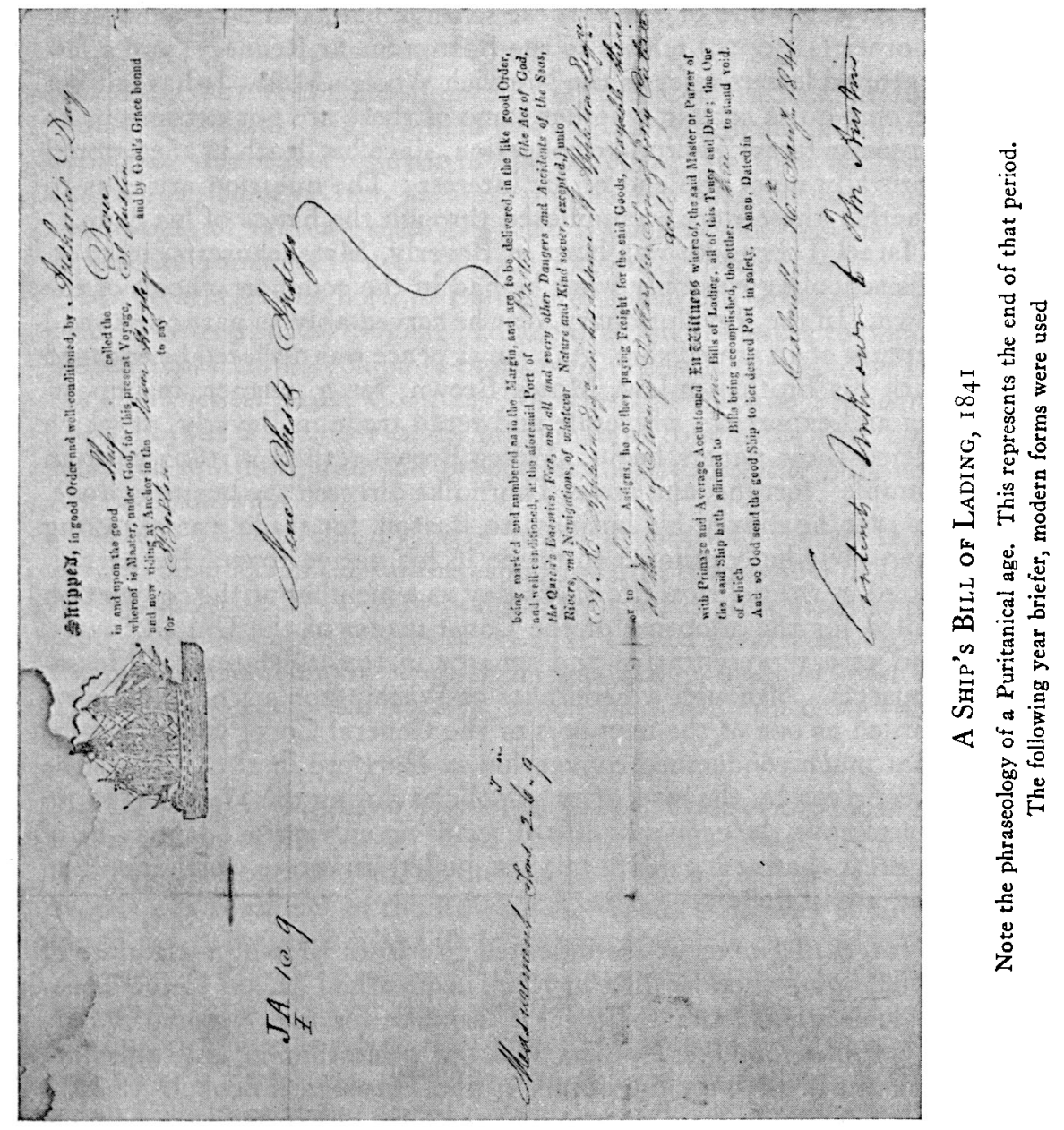


Israel Thorndike was one of the early ship owners who became interested in manufacturing. Certain letters mention some interest in the cotton trade; a small group of papers ( $182 \mathrm{I}-62$ ) is chiefly composed of bills for services rendered the Provident Institution for Savings, one of the earliest savings banks in Massachusetts; another (I850-59) relates to the Boston Sugar Refinery; and a few scattered letters refer to the Norwich Woolen Mills. It has not yet become quite certain whether some of these are not extraneous to a precise Israel Thorndike collection, since his death in 1832 would naturally mark the end of his interest. The question arises as to whether these were accumulated through the hands of his heirs.

Israel Thorndike was born in Beverly, Massachusetts, in I755. His schooling was only what he had in the common schools of the town. In the Revolutionary War he served ably as part owner and captain of an armed ship. As soon as peace was declared he engaged with his brother-in-law, Moses Brown, for a partner, in importing and exporting, wholesale and retail trade in Beverly, at which period these papers begin. Moses Brown retired in I 800 with an "ample" fortune, and Israel Thorndike directed the business alone. In 1810 he moved his business to Boston, for trade was centering there, but he continued to reside in his native town. He participated in the political life of his day as a member of the convention called for the adopting of the Constitution of the United States, and as a representative and senator in the legislature of Massachusetts. Although a Federalist of Washington's school, he is recorded as one of the members of the General Court who voted for that much-condemned convention at Hartford in $\mathbf{I}_{4}$, because he was driven by the insecurity of policies during the War of 1812 , to try to save the economic life of seafaring enterprise. It may be of interest that at his death in 1832 , he left an estate worth a million and a half dollars.

Harvard University is indebted to Moses Brown, a graduate of 1768 , who, when he died in 1820 , bequeathed $\$ 2,000$ to the Theological School; and to Israel Thorndike for five hundred dollars (1806) to found a Natural History professorship and an equal amount in 1818 for the library of the Theological School. In I 818 also, he bought from the agent of the King of Prussia an invaluable library, containing many books printed in the smaller houses of New England, and at that time already out of print, collected by Professor Ebeling of Hamburg, and presented it to Harvard University, "thereby securing to this country one of the most complete and valuable collections of works extant on American history." 